\title{
Derechos sociales y liberales Un balance sobre la discusión de 2004
}

María Beatriz Arriagada Cáceres*

Recepción: 31 de julio 2015.

Aceptación: 30 de agosto 2015.

Resumen: El primer objetivo de este trabajo es mostrar que el debate sostenido en el cuarto número de la revista Discusiones (2004), particularmente la intervención de Fernando Atria, modificó las coordenadas de la conocida controversia sobre la posibilidad o imposibilidad de equiparar los llamados derechos sociales con los llamados derechos liberales (civiles y políticos), exhibiendo que esta controversia está determinada por la tensión entre el concepto y el fundamento de los derechos fundamentales. Su segundo objetivo es analizar, en términos de sus fortalezas y limitaciones, la propuesta teórica de Fernando Atria y la forma en que esta ha evolucionado a más de una década de su formulación original. Su tercer objetivo es, a partir de este análisis, evaluar la contribución de esta propuesta en el mejoramiento de la situación devaluada en la que se encuentran los derechos sociales e identificar los desafíos que, en esta tarea, todavía se encuentran pendientes.

Palabras clave: derechos sociales, derechos liberales, derechos civiles y políticos.

\begin{abstract}
The first objective of this work is to show that the discussion held in the Discussions Journal Issue Number 4 (2004), particularly Fernando Atria's intervention, changed the coordinates of the wellknown controversy about the possibility or impossibility to equate the so called social rights with the so called liberal rights (civil and political rights), exposing that this controversy is determined by the tension between the concept and the basis of fundamental rights. Its

* Licenciada en Derecho Pontífica Universidad Católica de Chile. Doctora en Derecho Universidad de Chile. Profesora de Teoría del Derecho de la Universidad Diego Portales, Santiago de Chile.
\end{abstract}

Correos electrónicos: maria.arriagada@udp.cl; mbeatriz.arriagada@gmail.com. 
second objective is to analyze, in terms of its strengths and limitations, Fernando Atria's theoretical proposal and how it has evolved in more than a decade from its original formulation. Its third objective, starting from this analysis, is to assess the contribution of this proposal on improving the undervalued situation in which social rights are and identify the challenges that, in this task, are still pending.

Key words: social rights, liberal rights, civil and political rights.

\section{Introducción}

Aunque la conocida controversia sobre la posibilidad o imposibilidad de equiparar los llamados derechos sociales con los llamados derechos liberales ha ocupado una parte importante del trabajo de la dogmática constitucional de los derechos fundamentales, la teoría analítica del derecho ha sido la encargada de clarificar los términos de la discusión ${ }^{1}$. Este nivel de análisis permite vislumbrar que a la referida controversia subyace una disputa acerca del concepto de derecho subjetivo ${ }^{2}$.

1 Una de las funciones de esta forma de hacer teoría del derecho es analizar los conceptos utilizados por la dogmática jurídica y, en este sentido, es un metalenguaje acerca del lenguaje de los juristas. Ver por ejemplo Carrió, G., "Nota preliminar", en Hohfeld, W., Conceptos jurídicos fundamentales, México D.F., Fontamara, 1992 [1913], pág. 8, Nino, C., Introducción al análisis del derecho, Buenos Aires, Astrea, 1980, págs. 165-168 y Escudero, R., "Estudio preliminar", en Comanducci, P, Hacia una teoría analitica del derecho. Ensayos escogidos, Madrid, Centro de Estudios Políticos y Constitucionales, 2010, págs. XXXVII-XLVI.

2 Secundariamente, se han esgrimido otras razones para sostener que entre los derechos sociales y liberales existen diferencias que impiden su equiparación y, en consecuencia, otros argumentos que se dirigen a refutar estas diferencias; ver, por ejemplo, Ruiz Miguel, A., "Derechos liberales y derechos sociales," Doxa, números 15-16, 1994; Hierro, L., "Los derechos económico-sociales en la teoría de los derechos de Robert Alexy," en Alexy, R. (et.al), Derechos sociales y ponderación, Madrid, Fundación Coloquio Jurídico Europeo, 2007; Martínez de Pisón, J., "Los derechos sociales: unos derechos controvertidos," en Zapatero, V. y Garrido, M.I. (eds.), Los derechos sociales como una exigencia de la justicia, Madrid, Cuadernos democracia y derechos humanos, Universidad de Alcalá, 2009 y Rossetti, A., "Algunos 
En el entendido de que los derechos fundamentales son una especie de los derechos subjetivos, desde una perspectiva, se sostiene que los llamados derechos sociales no son derechos en sentido estricto porque no son judicialmente exigibles ${ }^{3}$. Desde la perspectiva opuesta, se afirma que la falta de garantía judicial no es una razón para negarle el carácter de derecho a una posición jurídica, además de que existen otras formas de garantía ${ }^{4}$.

Se puede, entonces, establecer que el argumento de que los derechos sociales son auténticos derechos y, por tanto, equiparables con los derechos liberales se sustenta en el concepto kelseniano de derecho reflejo. De acuerdo con este concepto, un derecho subjetivo no es otra cosa que el reflejo de una obligación de otro u otros ${ }^{5}$, o en términos de Hohfeld, la posición correlativa a la posición de deber ${ }^{6}$, cuyo fundamento jurídico es una norma regulativa que impone una obligación ${ }^{7}$. A su turno, el argumento según el cual los derechos sociales no son derechos en sentido estricto y, en consecuencia, no

mitos, realidades y problemas en torno a los derechos sociales", en Ribotta, S. y Rossetti, A. (eds.), Los derechos sociales en el siglo XXI. Un desafio clave para el derecho y la justicia, Madrid, Dykinson, 2010.

3 Por ejemplo, Böckenförde, E., Escritos sobre Derechos Fundamentales, BadenBaden, Nomos Verlagsgessellschaft, 2001 [1993], pág. 80 y Hesse, C., "Significado de los derechos fundamentales," en Benda et.al., Manual de Derecho Constitucional, Madrid, Evap-Marcial Pons, [1994], pág. 98.

4 Ver por ejemplo Alexy, R., Teoría de los derechos fundamentales, Madrid, Centro de Estudios Políticos y Constitucionales, 2007 [1984], pág. 456; Carbonell, M., "Eficacia de la Constitución y derechos sociales: esbozo de algunos problemas", Revista de Derecho Público Universidad de Chile, volumen 70, 2008, pág. 46 y Pérez Luño, A., Los derechos fundamentales, Madrid, Tecnos, 1984, pág. 66 y ss.

5 Kelsen, H., Teoría pura del Derecho, (2 $2^{a}$ edición), México D.F., Porrúa, 1991 [1960], págs. 139-143.

${ }^{6}$ Hohfeld, W., Conceptos jurídicos fundamentales, México D.F., Fontamara, 1992 [1913], págs. 47-52. Sobre esta coincidencia entre Hohfeld y Kelsen, ver por ejemplo Cruz Parcero, J., El lenguaje de los derechos. Ensayo para una teoría estructural de los derechos, Madrid, Trotta, 2007, pág. 37.

7 Una norma que obliga a cierta conducta enlazando a la contraria una sanción; Kelsen, H., Teoría pura, op. cit., pág. 140. 
son equiparables con los derechos civiles y políticos se sustenta en el concepto kelseniano de derecho subjetivo en sentido técnico, típicamente utilizado en el ámbito del derecho privado. De acuerdo con este concepto, un derecho subjetivo es un derecho reflejo provisto de la potestad de poner en movimiento, mediante una acción, el procedimiento destinado a reconocer la falta de cumplimiento de la obligación por el deudor ${ }^{8}$. Este concepto puede ser descrito como una conjunción de los conceptos hohfeldianos de derecho subjetivo y potestad ${ }^{9}$, y su fundamento jurídico reside, conjuntamente, en una norma regulativa y una norma de competencia ${ }^{10}$.

La teoría del derecho también ha puesto de relieve que la disputa acerca de la posibilidad o imposibilidad de equiparar a los derechos sociales con los derechos liberales está determinada por dos visiones ideológicamente opuestas. Mientras desde la mirada conservadora se afirma que entre los derechos sociales y liberales existen diferencias que impiden su equiparación, desde la perspectiva progresista

8 O lo que es lo mismo, el poder de participar en la producción de la norma jurídica individual de la sentencia judicial en la que se estatuye una sanción concreta por dicho incumplimiento; Kelsen, H., Teoría pura, op. cit., págs. $146-149$ y 152 . Desde esta perspectiva, los derechos sociales se consideran derechos sobre el papel y no derechos verdaderos como los derechos civiles y políticos; Guastini, R., Distinguiendo. Estudios de teoría y metateoría del derecho, Barcelona, Gedisa, 1999 [1996], págs. 185-186 y 188-189. Asimismo de acuerdo con Hart, solo se puede afirmar que los individuos tienen derecho a los beneficios de bienestar que el Estado está obligado a proporcionarles cuando se cumplen dos condiciones: (i) la obligación estatal debe ser condicional, en el sentido que depende de que sea demandada por los beneficiarios; y (ii) el beneficiario que ha sufrido algún daño debe encontrarse en una posición que lo legitime para solicitar a un tribunal la dictación de una orden dirigida a que el organismo oficial pertinente cumpla con su obligación o deje de incumplirla; Hart, H.L.A., "Legal Rights" en Essays on Bentham. Studies in Jurisprudence and Political Theory, New York, Oxford University Press, 1982, págs. 185-186.

9 Hohfeld, W., op. cit., págs. 47-52 y 67-81.

${ }^{10}$ En términos de Kelsen, una norma facultativa perteneciente a la categoría de las "normas no independientes" porque solo determina una de las condiciones a las cuales una norma independiente enlaza el acto coactivo; Kelsen, H., Teoría pura, op. cit., pág. 68. 
se sostiene exactamente lo opuesto ${ }^{11}$. En este contexto, las expresiones "conservadurismo" y "progresismo" pueden ser respectivamente sustituidas por las expresiones "centro derecha" y "centro izquierda"12 o "liberalismo europeo y latinoamericano" (o libertariano) y "liberalismo anglosajón" (o igualitario) ${ }^{13}$, en el entendido de que se trata de dos posiciones filosófico-políticas o teorías de la justicia que ofrecen diversas justificaciones para conferir derechos fundamentales.

Lo expuesto permite proponer, cuando menos en principio, la existencia una correlación entre las respuestas que se dan a dos cuestiones diferentes: el concepto y el fundamento de los derechos fundamentales. En particular es posible correlacionar: (i) el concepto de derecho subjetivo en sentido técnico con la justificación conservadora de los derechos fundamentales y (ii) el concepto de derecho subjetivo reflejo con la justificación progresista de los derechos fundamentales. El establecimiento de estas correlaciones está, por así decirlo, en el límite de la teoría analítica del derecho puesto que, al mismo tiempo que ella ofrece explicaciones acerca del modo en que los especialistas utilizan conceptos de aplicación general al interior de su campo, pone de manifiesto las relaciones que existen entre diferentes compartimentos de nuestra vida intelectual y humana ${ }^{14}$.

La correlación entre el concepto de derecho subjetivo reflejo y el fundamento progresista de los derechos fundamentales no es, sin embargo, más que un punto de partida. Conscientes de que buena parte del escepticismo sobre los derechos sociales se debe a lo problemática y deficiente que ha sido su protección y cumplimiento, sus

${ }^{11}$ Por ejemplo, Ruiz Miguel, A., "Derechos liberales y derechos sociales", op. cit., págs. 652-654. Sobre la dicotomía "conservadurismo-progresismo" ver Bonazzi, T., "Conservadurismo" en Bobbio, N., Mateucci, N. y Pasquino, G., Diccionario de política, México D.F., Siglo XXI, 2007 [1983], págs. 318-323.

${ }^{12}$ Bobbio, N., Derecha e izquierda. Razones y significados de una distinción politica, Madrid, Taurus, 1996, pág. 163.

${ }^{13}$ Villavicencio, L., Las criticas comunitaristas al liberalismo igualitario. Un balance, Madrid, Dykinson, 2014, págs. 9 y 14.

${ }^{14}$ Sobre esta característica del análisis conceptual, ver Strawson, P., Análisis y metafísica, Barcelona, Paidós, 1997 [1992], págs. 47-57. 
defensores han procurado encontrar fórmulas para garantizarlos jurídicamente. En este contexto, lo ideal sería encontrar el modo de hacer posible su tutela judicial ${ }^{15}$.

La paradoja se vuelve entonces evidente: la defensa de los derechos sociales, inicialmente fundada en el concepto de derecho subjetivo reflejo, termina por disolverse en un alegato a favor de su transformación en derechos subjetivos en sentido técnico. Como los derechos sociales se encuentran devaluados y son tan importantes como los derechos liberales, deben ser, igual que estos últimos, justiciables ${ }^{16}$. Esta era ya en el año 2004 la nueva ortodoxia del constitucionalis$\mathrm{mo}^{17}$, cuyo caso paradigmático está constituido por quienes promueven la justiciabilidad de los derechos sociales bajo formas convertidas de derechos liberales que sí cuentan con recursos que garantizan su exigibilidad judicial ${ }^{18}$.

La controversia podía entonces ser descrita como una que enfrentaba a juristas de tendencia marcadamente conservadora, que tendían a negar la justiciabilidad de los derechos sociales, con juristas progresistas con una firme tendencia a aceptar que los derechos sociales

${ }^{15}$ Cruz Parcero, J., El lenguaje de los derechos, op. cit., pág. 71.

${ }^{16}$ Así por ejemplo, hay quienes consideran que para afirmar la exigibilidad de estos derechos es suficiente el reconocimiento jurídico de algún poder de reclamo aunque este no exista en todos los casos de violaciones; Abramovich, V. y Courtis, C., Los derechos sociales como derechos exigibles, Madrid, Trotta, 2004, pág. 38, nota 37 de ese trabajo. También hay quienes afirman que la posibilidad de reclamar existe a partir de la eficacia directa de la norma iusfundamental; Bastida, F., "¿Son los derechos sociales derechos fundamentales? Por una concepción normativa de la fundamentalidad de los derechos," en Alexy, R. et.al.)Derechos sociales y ponderación, Madrid, Fundación Coloquio Jurídico Europeo, 2007, págs. 116-119.

${ }^{17}$ Michelon, C., "Introducción: derechos sociales y la dignidad de la igualdad", Discusiones, 4, pág. 8.

${ }^{18}$ Por ejemplo, Rossetti, A., op. cit., pág. 121 (nota 54 de ese trabajo) y RuizTagle, P., "Un proyecto constitucional para la generación del bicentenario: Igualdad y derechos sociales y económicos en Chile," Revista de Derecho y Humanidades, 15, 2009, pág. 23. 
pueden ser directamente utilizados como fundamento para una decisión judicial ${ }^{19}$.

El autor chileno Fernando Atria identificó correctamente la paradoja envuelta en el discurso progresista y sus implicaciones. Al retratar la situación en la que se encuentran las demandas socialistas que dieron origen a la idea de derechos sociales, consiguió levantar la venda de optimismo que había cubierto la visión de esta doctrina ${ }^{20}$. Al defender la imposibilidad de equiparar los derechos sociales con los derechos liberales no solo fue decididamente en contra de todo lo que rápidamente se estaba estableciendo como la ortodoxia constitucional ${ }^{21}$, sino que también logró modificar las coordenadas de la controversia descrita, mostrando que la afirmación de que los derechos sociales son diferentes a los derechos civiles y políticos no implica necesariamente una alineación con la postura conservadora ${ }^{22}$.

La importancia teórica de su propuesta reside en que consiguió exhibir que la tensión entre el concepto y el fundamento de los llamados derechos sociales no estaba resuelta. Además, inauguró un auténtico discurso contracultural que ha derivado en la propuesta de

${ }^{19}$ Michelon, C., op. cit., pág. 8.

${ }^{20}$ Atria, F., “¿Existen derechos sociales?”, Doxa 4, 2004.

${ }^{21}$ Así lo explicita el propio Atria; ver Atria, F., "Réplica: derecho y política a propósito de los derechos sociales," Discusiones, 4, 2004, pág.145.

22 Como apunta Bernal, lo novedoso en la propuesta de Atria es que la negación del carácter vinculante de las disposiciones de derechos sociales se hace compatible con una profunda fidelidad a las doctrinas socialistas; Bernal, C., "Fundamento, concepto y estructura de los derechos sociales. Una crítica a ‘Existen los derechos sociales?' de Fernando Atria”, Discusiones, 4, 2004, pág. 118. Una década más tarde, Atria admite que su tesis de que los derechos sociales no pueden ser judicialmente exigibles parece alinearlo con la constitución chilena de Pinochet (en la que los 1lamados derechos sociales no son exigibles judicialmente). Su libro (de 2014) pretende ser una explicación de que por qué esto es solo apariencia; Atria, F., Derechos sociales y educación. Un nuevo paradigma de lo público, Santiago, LOM, 2014, pág. 35 (nota 13 de ese trabajo). 
un nuevo modelo y un cambio de paradigma ${ }^{23}$, cuyo análisis crítico es crucial para explicitar la tensión existente entre el concepto y el fundamento de los derechos civiles y políticos y, en esa medida, avanzar en la resolución de la tensión entre el concepto y el fundamento de los derechos fundamentales en general.

Fundamentar los derechos, es decir, responder a la pregunta de cuáles son las razones extrajurídicas que justifican su otorgamiento no es una tarea propia de la teoría del derecho sino de la filosofía política $^{24}$. A la teoría del derecho le compete resolver el problema conceptual, esto es, responder a las preguntas sobre bajo qué condiciones es posible afirmar que alguien tiene un derecho y qué significa afirmar que lo tiene ${ }^{25}$, las cuales dicen relación con la estructura normativa de estas posiciones jurídicas subjetivas. Pero ello no significa ignorar que los dos problemas están relacionados. De ahí que pueda hablarse propiamente de una "tensión"26.

La propuesta teórica de Fernando Atria tuvo el mérito de poner al descubierto que la controversia sobre la posibilidad o imposibilidad

${ }^{23}$ Ver Atria, F., Larraín, G., Benavente, J., Couso, J., y Joignant, A., El otro modelo. Del orden neoliberal al régimen de lo público, Santiago, Debate, 2013 y Atria, F., Derechos sociales y educación. Un nuevo paradigma de lo público, op. cit.

${ }^{24}$ En este sentido por ejemplo, Prieto Sanchís, L., Estudios sobre derechos fundamentales, Madrid, Debate, 1990, págs. 17-18 y De Cabo, A., y Pisarello, G., "Ferrajoli y el debate sobre los derechos fundamentales" en De Cabo, A y Pisarello, G. (eds.), Los fundamentos de los derechos fundamentales, Madrid, Trotta, 2007 [2001], pág. 17.

${ }^{25}$ Estas dos preguntas pueden denominarse, respectivamente, "pregunta de la identidad" y "pregunta de la implicación"; Shapiro, S., Legalidad, Madrid, Marcial Pons, 2014 [original de 2011], págs. 33-36.

${ }^{26}$ Como por un lado, la elucidación conceptual no podría efectuarse con independencia de la elaboración de la teoría normativa en cuyo marco opera el concepto y, por otro lado, la valoración no podría tener lugar sin la previa identificación conceptual de lo que se valora, se requiere de un proceso de ajustes mutuos; Nino, C., Ética y derechos humanos. Un ensayo de fundamentación, Astrea, Buenos Aires, 1989 [original de 1984], págs. 12-13. Sobre esta tensión ver también Prieto Sanchís, L., op. cit., págs. 17-23 y Baccelli, L., "Derechos sin fundamento" en De Cabo, A. y Pisarello, G. (eds.), Los fundamentos de los derechos fundamentales, Madrid, Trotta, 2007 [original de 2001]. 
de equiparar derechos liberales y sociales está determinada por esta tensión entre el concepto y fundamento de los derechos fundamentales. Mostrar esto y analizar esta propuesta y su evolución, en miras de evaluar su contribución en el mejoramiento de la situación en que se encuentran los derechos sociales e identificar los desafíos que, en esta tarea, todavía están pendientes es el sentido de las páginas que siguen.

\section{La primera propuesta de Atria}

La primera formulación de Atria sobre la diferencia entre los derechos civiles y políticos y los derechos sociales se presenta en dos artículos publicados en el cuarto número de la revista Discusiones. El primero de ellos contiene la formulación original y el segundo complementa esta formulación respondiendo a los comentarios de Bernal, Cruz Parcero y Gargarella publicados en el mismo volumen ${ }^{27}$. La propuesta puede sintetizarse en las siguientes tres tesis:

Primera Tesis: un derecho subjetivo es una posición de potestad en la que se encuentra un individuo para decidir si la obligación que otro $\mathrm{u}$ otros tienen, en interés del primero, será o no coactivamente exigida.

El eje de la primera propuesta de Atria es el concepto de derecho subjetivo típicamente usado en el ámbito del derecho privado, definido en los siguientes términos:

[P]ara que en sentido jurídico podamos hablar de un derecho subjetivo es necesario que una persona (i) tenga una obligación (ii) cuya exigibilidad está jurídicamente mediada por la declaración de voluntad de otra; y (iii) que sea reconocida o creada por el derecho en atención al interés de esa otra ${ }^{28}$.

${ }^{27}$ Atria, F., “¿Existen derechos sociales?”, op. cit. y Atria, F., "Réplica: derecho y política a propósito de los derechos sociales, op. cit.; Bernal, C., Fundamento concepto y estructura de los derechos sociales, op. cit.; Cruz Parcero, J., "Réplica a Fernando Atria", Discusiones, 4, 2004 y Gargarella, R., "Derecho y disociación. Un comentario a "¿Existen los derechos sociales?' de Fernando Atria," Discusiones, 4, 2004.

${ }^{28}$ Atria, F., “¿Existen derechos sociales?”, pág. 23, op. cit. 
Desde esta óptica, decir que alguien tiene derecho es más que decir que es lícito, bueno o justo dar, hacer o no hacer algo en favor de ese alguien: "Para el derecho, lo crucial para que podamos hablar de un derecho subjetivo en el sentido jurídico es la posición en la que se encuentra una persona con potestad para decidir si la obligación de otro será o no coactivamente exigida", o lo que es lo mismo, "que la exigibilidad de la obligación del deudor esté mediada por la voluntad del acreedor" 29 .

Esta característica del concepto jurídico de derecho sería reflejo de una característica moral análoga, a saber, que el derecho (en sentido moral) significa recortar el rango de consideraciones morales aplicables a la determinación de la justicia de una acción, porque dado el contexto en el que en el derecho aparece lo dominante es cómo es servido el interés del acreedor. Jurídicamente esta nota se manifestaría a través de la exigibilidad mediada, puesto que el derecho entendería que, salvo en casos especiales, quien mejor conoce sus intereses es el propio interesado ${ }^{30}$.

Segunda tesis: los llamados derechos sociales son diferentes a los derechos civiles y políticos porque no pueden expresarse en el lenguaje de los derechos subjetivos.

En palabras de Atria: "Que el discurso jurídico no puede acomodar los derechos sociales como puede acomodar los derechos civiles y políticos no es solo un hecho casual: tiene que ver con el concepto mismo de derecho (subjetivo)" 31 .

${ }^{29}$ Ibídem, págs. 22 y 25. Dicho con otras palabras: "Que el derecho no reconozca una acción a una determinada pretensión quiere decir, como hemos visto, que esa pretensión no constituye un derecho subjetivo en el sentido propio del término". "Lo determinante no es la cultura jurídica del país del caso, porque para el derecho no hay derechos subjetivos sin acción (en otras palabras: en la 'cultura jurídica' occidental la idea jurídica de derecho subjetivo está siempre y necesariamente, no contingentemente, vinculada a la acción para exigir el cumplimiento coactivo)"; ibídem, págs. 43 y 47.

${ }^{30}$ Ibídem, pág. 25.

${ }^{31}$ Ibidem, pág. 51. 
Los derechos civiles y políticos son, según Atria, derechos subjetivos porque en ellos está implicada la idea liberal de que el interés individual se impone frente a los intereses de la comunidad. Atria admite que la idea de derecho subjetivo propia del derecho privado ha mutado en algo diferente cuando se usa para aludir a los derechos humanos como el derecho a la integridad física o a la participación política. Pero lo importante es, a su parecer, lo que no ha mutado: "[E]1 concepto mismo de derecho subjetivo, implica que el interés individual que el derecho protege triunfa, al menos típicamente las aspiraciones comunitarias. Quien reclama un derecho se separa de la comunidad y afirma su derecho aun en contra de ella si es necesario" 32 .

Los derechos sociales, a su turno, no podrían expresarse en el lenguaje de los derechos subjetivos porque ellos manifiestan una idea socialista opuesta a la que está implicada en el concepto de derecho subjetivo. Atria afirma que estos derechos constituyen una manera más completa de concebir la ciudadanía y son consecuencia de una nueva forma de concebir la asociación comunitaria en la cual cada uno de sus miembros tiene interés en el bienestar del otro ${ }^{33}$. Como manifiestan una idea de comunidad fundada en la solidaridad, reciprocidad e igualdad, en la que ciertos aspectos de nuestra existencia son preocupación de todos y no de cada uno, la noción misma de derechos sociales implica una contradicción en los términos que la designan. La idea comunitaria a la que el socialismo apela no puede traducirse a la lengua de los derechos, sobre cuya base se estructura una forma de asociación en la que sus miembros fundan sus relaciones en el interés individual ${ }^{34}$.

La razón por la cual los derechos civiles y políticos pueden traducirse al lenguaje de los derechos subjetivos es, según Atria, que en su formulación no hay referencia a la vida en comunidad. Estos derechos

32 Ibídem, págs. 51-52.

${ }^{33}$ Ibídem, pág. 32. Atria sigue en esto a Marshall, T.H., Ciudadanía y clase social, Madrid, Alianza, 1998 [1950].

${ }^{34}$ Atria, F., “¿Existen derechos sociales?”, págs. 15, 22, op. cit. y Atria, F., "Réplica: derecho y política a propósito de los derechos sociales", págs. 52 y 147 , op. cit. 
(de primera generación) habrían sido originalmente concebidos como derechos del individuo en contra de la comunidad política, de suerte que esta se justificaba justamente por la protección de los derechos que aseguraba. Vinculado con lo anterior, la posibilidad misma de concebirlos como derechos naturales se explicaría por la forma en que se determina su contenido. Para especificar el contenido tanto activo como pasivo de los derechos civiles y políticos sería suficiente atender a la posición del individuo aislado. Del hecho de que alguien tenga un derecho se seguiría que todos y cada uno de los individuos restantes tienen el deber de no interferir con la conducta lícita del otro ${ }^{35}$.

Como para la tradición socialista, el valor de la comunidad política reside en que ella posibilita una forma de vida en la que sus miembros pueden relacionarse, no mirando exclusivamente su autointerés, sino sobre la base de la solidaridad, los derechos sociales serían completamente ajenos a la idea de que la comunidad política se justifica por la protección de los derechos naturales. Como en los derechos sociales la pregunta sobre quién es el obligado y cuál es el contenido de la obligación solo sería posible cuando los individuos viven en sociedad, la especificación de su aspecto activo no constituiría una especificación completa del contenido de su aspecto pasivo. La caracterización del contenido de estos derechos solo podría completarse considerando que ellos configuran una forma diferente de comunidad, en la que esta, como un todo, se preocupa del bienestar de cada uno de sus miembros ${ }^{36}$.

Tercera tesis: no existen derechos sociales. Judicializar una demanda socialista es convertirla en una demanda liberal.

Los intentos de la doctrina progresista por hacer exigibles los derechos sociales están, según Atria, condenados al fracaso, porque la juridificación buscada cobra el precio de desocializar (privatizar) las demandas socialistas, convirtiéndolas en auténticas demandas liberales:

${ }^{35}$ Atria, F., “¿Existen derechos sociales?”, págs. 16-17 y 19-20, op. cit. y Atria, F., "Réplica: derecho y política a propósito de los derechos sociales," págs. 48-149, op. cit. 
Derechos sociales y liberales. Un balance sobre la discusión de 2004

Lo que llega al tribunal no es un derecho social, no puede ser un derecho social, sino una demanda privada, que expresa ya no la idea de una forma superior de comunidad sino la negación de esta: la pretensión del demandante de que su interés sea atendido, aun a costa del interés de los demás ${ }^{37}$.

Se debe aclarar que, desde el punto de vista de Atria, hay, junto con la socialista, una manera liberal de entender los derechos sociales. En esta tradición ellos habrían tenido que fundarse en una noción más amplia del autointerés (una capaz de contemplar la existencia de un seguro frente a la posibilidad de que los sujetos se encuentren necesitados), y ser entonces concebidos como derechos a un mínimo de bienestar dirigido a asegurar la satisfacción de necesidades básicas. La distinción entre la eliminación de la pobreza y la eliminación de la desigualdad nos daría una clave para distinguir, respectivamente, entre una concepción liberal y una socialista de los derechos sociales. ${ }^{38}$

La manera en que los derechos sociales habrían sido entendidos por la tradición liberal se explica, según Atria, porque las demandas socialistas no habrían tenido otra alternativa que formularse en el lenguaje de los derechos. Si se manifestaban en el lenguaje de la aspiración comunitaria no podían competir con los derechos que, en el discurso liberal, en principio, solo conocían como límites otros derechos. Los liberales, por su parte, habrían acogido la idea de derechos sociales, pero no en el sentido socialista (o social-demócrata) sino como derechos a un mínimo dirigido a eliminar la pobreza, no la desigualdad. Y así entendidos, estarían dirigidos a conseguir que los sujetos de mercado desarrollen su propia autonomía en lugar de a obtener ciudadanos iguales ${ }^{39}$.

${ }^{37}$ Ibídem, pág. 46.

${ }^{38}$ Atria, F., “Existen derechos sociales?”, págs. 31-32, op. cit. y Atria, F., "Réplica: derecho y política a propósito de los derechos sociales", págs. 146-147, op. cit.

${ }^{39}$ Atria, F., “¿Existen derechos sociales?” págs. 27-32, op. cit. y Atria, F., "Réplica: derecho y política a propósito de los derechos sociales", págs. 147-148, op. cit. 
La conclusión de Atria es que el derecho no es lo suficientemente neutral o dúctil para expresar sin distorsiones el conflicto político entre liberalismo y socialismo que se traduce en la confrontación entre derechos civiles y políticos, por un lado, y derechos sociales, por el otro. A su juicio, en el contexto en cual tiene lugar un consenso cada vez más extendido sobre la idea de que los derechos humanos son parasitarios respecto de los derechos subjetivos y, por consiguiente, un aumento de la importancia política de los tribunales, una manera de explicar por qué el discurso jurídico no podría expresar sin tergiversaciones las pretensiones políticas, es justamente considerar la discusión acerca de la relevancia de los derechos sociales ${ }^{40}$.

El fracaso de los intentos de torcer la forma del derecho para adecuarlo al contenido de los derechos sociales (el hecho que ellos no puedan ser jurídicamente exigibles sino cambiando su significado socialista por uno liberal) evidenciaría la contradicción implicada en la noción misma de derechos sociales ${ }^{41}$ y su diferencia con los derechos civiles y políticos.

\section{Las fortalezas y limitaciones de la primera propuesta de Atria}

Las conclusiones de Atria están correctamente justificadas si tener un derecho significa lo que Atria cree. La constitución tendría la pretensión de permitir la expresión de todas las visiones políticas pero, en lugar de ser neutral, privilegiaría una concepción (liberal) de la ciudadanía y los derechos silenciando a la otra (socialista) ${ }^{42}$. De ahí se concluye que: (i) el derecho no es lo suficientemente dúctil; (ii) los derechos sociales son diferentes a los derechos civiles y políticos porque no pueden traducirse al lenguaje liberal de los derechos

\footnotetext{
${ }^{40}$ Atria, F., “¿Existen derechos sociales?”, págs. 33-39, op. cit.

${ }^{41}$ Ibídem, págs. 40-51.

${ }^{42}$ Atria, F., "Réplica: derecho y política a propósito de los derechos sociales", págs. 148, op. cit.
} 
Derechos sociales y liberales. Un balance sobre la discusión de 2004

subjetivos; (iii) los derechos sociales judicialmente exigibles son auténticos derechos liberales; y (iv) no existen derechos sociales.

Se puede sostener que, al alcanzar estas conclusiones, Atria no parece tener suficientemente presente que no hay un solo concepto de derecho subjetivo, no solo porque este ha variado a través del tiempo ${ }^{43}$, sino también porque, incluso en un mismo momento, coexisten diferentes respuestas a la pregunta de qué es un derecho subjetivo ${ }^{44}$, las cuales compiten por ofrecer un concepto más exacto y apropiado de acuerdo con algún criterio teórico ${ }^{45}$. Este fue, de hecho, uno de los puntos más debatidos en el año 2004, particularmente por Cruz Parcero.

Según este autor, la noción de derecho subjetivo que Atria utiliza responde a una concepción positivista y particularmente kelseniana, según la cual los derechos subjetivos, en sentido estricto, son poderes de un sujeto para demandar al Estado el cumplimiento de un deber jurídico por parte de otro. Ella contrastaría con otras concepciones, como la hohfeldiana, que suelen ver el núcleo del concepto en lo que Kelsen consideraba superfluo: la idea de derecho como reflejo de una

${ }^{43}$ Aun cuando su origen moderno haya sido bien fundamentado, la noción de derecho subjetivo ha tenido un campo de significación muy amplio y heterogéneo; ver por ejemplo Villey, M., Estudios en torno a la noción de derechos subjetivos, Valparaíso, Ediciones Universitarias, 1976 y Finnis, J., Ley natural y derechos naturales, Buenos Aires, Abeledo Perrot, 2000 [1980], págs. 227-259.

${ }^{44} \mathrm{El}$ estudio de los llamados conceptos jurídicos fundamentales o básicos en la teoría del derecho y, en ese contexto, el examen de los diferentes usos de la expresión derecho subjetivo es una prueba de ello; ver por ejemplo Hohfeld, W., op. cit., y Kelsen, H., Teoría pura, op. cit., pág. 138 y ss.

${ }^{45}$ Aunque como sugiere Bulygin a propósito del concepto de Derecho, si bien hay varios conceptos diferentes, la diversidad de explicaciones también puede ser descrita, siguiendo a Rawls y a Dworkin, como diferentes concepciones del mismo concepto; Bulygin, E., "Raz y la teoría del derecho. Comentarios sobre '¿Puede haber una teoría del derecho?' de Joseph Raz", en Raz, J., Alexy, R. y Bulygin, E., Una discusión sobre la teoría del derecho, Madrid, Marcial Pons, 2007, págs. 106-108. Sobre la diferencia entre concepto y concepción, ver Rawls, J., Teoría de la justicia, México D.F., Fondo de Cultura Económica, 1995 [original de 1971], págs. 20-24 y Dworkin, R., El imperio de la justicia, Barcelona, Gedisa, 1998 [1986], págs. 60-62. 
obligación. El problema de usar esta noción residiría en que ella identifica los derechos con las acciones procesales para reclamarlos ${ }^{46}$.

La crítica de Cruz Parcero no está bien formulada por al menos dos razones. La primera es que esta forma de entender los derechos subjetivos tiene antecedentes iusnaturalistas muy anteriores al surgimiento del Positivismo jurídico. Podría encontrarse, aunque de forma poco clara, en la cualidad moral del sujeto en virtud de la cual se puede hacer o tener algo lícitamente que Grocio identifica como una de las acepciones posibles que puede adoptar la palabra "ius" cuando es extraída del sujeto, la cual en caso de ser perfecta, se denomina facultad. Asimismo Pufendorf, al definir el derecho como una cualidad moral en virtud de la cual algo nos es debido, puntualiza que quien infringe un derecho perfecto hace un mal que da a la parte perjudicada una base para ejercitar, en un tribunal humano, una acción en su contra. Pero sobre todo, Thomasius que, junto con precisar que el derecho y la obligación son conceptos correlativos, sostiene, en contra de la división entre derecho perfecto e imperfecto, que todo derecho es perfecto, aduciendo que la obligación que corresponde al derecho es siempre externa y sujeta a coacción por parte de otros hombres ${ }^{47}$.

La segunda razón consiste en que no es efectivo que la noción de derecho subjetivo empleada por Atria sea atribuible a Kelsen en la forma sugerida por Cruz Parcero. Esta noción corresponde aproximadamente al concepto kelseniano de derecho subjetivo en sentido

${ }^{46}$ Cruz Parcero, J., "Leones, lenguaje y derechos. Sobre la existencia de los derechos sociales. Réplica a Fernando Atria", págs. 73 y 82, op. cit. y Cruz Parcero, J., El lenguaje de los derechos, pág. 77, op. cit.

${ }^{47}$ Ver Grocio, H., Del derecho de presa y Del derecho de la guerra y de la paz. Textos de las obras "De iure Predae" y "De Iure Belli ac Pacis", Madrid, Centro de Estudios Constitucionales, 1987 [1625], págs. 53-54 (Capítulo I, III, 1 y 2 y IV); Pufendorf, S., The Books of Elements of Universal Jurisprudence, Indianápolis, Liberty Fund, 2009 [1660], págs. 91-92 (libro I, definición VIII, 1 y 2); y Thomasius, C., Fundamentos de derecho natural y de gentes, Madrid, Tecnos, 1994 [1705], págs. 212-213 (capítulo V, párrafos VIII, IX, XXI-XXV). 
técnico ${ }^{48}$, pero este es solamente uno de los sentidos en que la doctrina tradicional usa la expresión derecho subjetivo que Kelsen identifica. Como es un derecho reflejo unido al poder jurídico de reclamar por el incumplimiento de la obligación ${ }^{49}$, su reconstrucción no solo exige una referencia a la norma que confiere este poder ${ }^{50}$, es también necesaria una referencia a la norma que fundamenta la obligación cuyo correlativo es el derecho reflejo. La superfluidad que Cruz Parcero cree que Kelsen atribuye al concepto de derecho reflejo solo puede explicarse como una errónea interpretación de la superfluidad que Kelsen atribuye a la exposición o descripción de ciertas situaciones jurídicas mediante ese concepto, de cuya importancia no cabe dudar ${ }^{51}$.

$\mathrm{Al}$ margen de estas consideraciones, lo relevante es que, reivindicando el concepto de derecho de reflejo, Cruz Parcero critica a Atria argumentando que la acción procesal no es más que un instrumento para la protección de los derechos sociales, que no tenemos que ver en ella la única forma de garantizar un derecho, y que quizá, en el caso de los derechos sociales, tampoco sea la más adecuada ${ }^{52}$. Pero a ello puede responderse, como hace Atria, aclarando que: (i) su postura no significa que él no reconozca la diferencia entre el derecho subjetivo y la

${ }^{48}$ En efecto, cuando Atria afirma que para el derecho lo crucial, para que podamos hablar de un derecho subjetivos es la posición en la que se encuentra una persona con potestad para decidir si la obligación de otro será o no coactivamente exigida, respalda su afirmación haciendo referencia a las páginas 147 y 148 de la "Teoría pura del derecho", donde Kelsen precisamente reconstruye el derecho subjetivo en sentido técnico; ver Atria, F., "¿Existen derechos sociales?”, pág. 22, op. cit. y nota 20 del mismo trabajo.

${ }^{49}$ Kelsen, H., Teoría pura, págs. 147-148, op. cit.

${ }^{50}$ Kelsen afirma que, precisamente, a esa norma jurídica se alude cuando en la terminología tradicional se habla de un derecho subjetivo en sentido técnico, como de un poder otorgado al individuo que en realidad es un derecho reflejo provisto de un poder jurídico; ibídem, pág. 148.

${ }^{51}$ Ibídem, págs. 140-142 y 147. Sobre la errónea interpretación de Cruz Parcero, ver Arriagada, MB., "Los derechos sociales: únicos derechos fundamentales", en Aguilar, G. (ed.), Derechos económicos, sociales y culturales en el orden constitucional chileno, Santiago, Librotecnia, 2012, págs. 73-74.

${ }^{52}$ Cruz Parcero, J., "Leones, lenguaje y derechos. Sobre la existencia de los derechos sociales. Réplica a Fernando Atria", pág. 85, op. cit. 
acción judicial para exigir su cumplimiento, sino solamente que para el derecho estas dos cosas van siempre juntas ${ }^{53}$; y (ii) los derechos sociales serían siempre derechos devaluados puesto que no gozarían de la marca que distingue a los derechos civiles y políticos: la acción procesal ${ }^{54}$.

La propuesta teórica de Atria tiene entonces el acierto de mostrar las consecuencias de adoptar la postura progresista y, junto con ello, que la tensión entre el concepto y el fundamento de los derechos sociales no ha sido resuelta, al punto que hablar de derechos sociales (en los términos del discurso progresista) puede ser considerado una contradicción.

Es efectivo, como sostiene Michelon, que el argumento de Atria no es empírico. Pero lo que Michelon entiende como un intento de demostrar que hay una incompatibilidad conceptual entre el principio de repartición igualitaria de (al menos ciertos tipos de) bienes y la estrategia de garantizar esta igualdad mediante la atribución de un derecho subjetivo justiciable a esos bienes a todos los ciudadanos ${ }^{55}$ no es otra cosa que un intento de exhibir que el fundamento para conferir derechos sociales es incompatible con el concepto de derecho subjetivo, es decir, que en la comprensión de la doctrina progresista hay una tensión no resuelta entre el concepto y el fundamento de los derechos sociales $^{56}$.

${ }^{53}$ Atria, F., "Réplica: derecho y política a propósito de los derechos sociales", pág. 162, op. cit.

${ }^{54}$ Ídem, pág. 163.

${ }^{55}$ Michelon, C., "Introducción: derechos sociales y la dignidad de la igualdad", pág. 9, op. cit.

${ }^{56}$ Atria se refiere a esta tensión en los siguientes términos: "[M]ucho esfuerzo e inteligencia se ha gastado en ofrecer una noción de derechos sociales que sea razonable. Sin embargo, persiste siempre una tensión (...) entre mirar a la sustancia contingente del derecho puesto a su forma necesaria de operación (...) para explicar la especial (devaluada) posición que ocupan los derechos sociales frente a los derechos de primera generación en los sistemas jurídicos occidentales”; Atria, F., “Existen derechos sociales?”, pág. 40, op. cit. (Las cursivas son del autor). Bernal interpreta correctamente a Atria cuando señala que la contradicción tiene lugar entre la exigibilidad como modo operativo de los derechos sociales y el fundamento de estos, es decir, la idea de comunidad fundada en el principio de solidaridad; Bernal, C., 
Derechos sociales y liberales. Un balance sobre la discusión de 2004

El principal desacierto de esta propuesta de Atria consiste en que ella no distingue correctamente el concepto del fundamento de los derechos subjetivos y, por tanto, de los derechos civiles y políticos que son el punto de referencia que permite calificar a los derechos sociales como inexistentes o al menos como derechos devaluados. Este problema se presenta por dos razones.

La primera de ellas es que el concepto de derecho subjetivo que Atria emplea parece estar comprometido, al mismo tiempo, con la teoría del interés y la teoría de la voluntad. Ello enciende una luz de alerta desde el momento que se trata de dos teorías que históricamente se han disputado la mejor explicación de los derechos subjetivos ${ }^{57}$. Aunque Atria reconoce que parece estar suscribiendo una teoría ecléctica (entre voluntad e interés), descarta pronunciarse explícitamente sobre ello ${ }^{58}$, con lo cual el punto queda sin explicación. Y la cuestión es relevante porque la adscripción a una de estas teorías implica una

"Fundamento, concepto y estructura de los derechos sociales. Una crítica a ¿Existen los derechos sociales? de Fernando Atria”, pág. 105, op. cit.

${ }^{57}$ En términos muy sintéticos, de acuerdo con la primera, $x$ tiene un derecho subjetivo frente a $y$ cuando el deber que $y$ tiene hacia $x$ le ha sido impuesto en interés de $x$. De acuerdo con la segunda, $x$ tiene un derecho subjetivo frente a $y$ cuando $x$ tiene el poder de entablar una acción judicial en el caso de que $y$ deje de cumplir con su deber. Una defensa de la teoría de la voluntad se encuentra en Hart, H.L.A., "Definición y teoría en la ciencia judical", en Derecho y moral. Contribuciones a su análisis, Buenos Aires, Depalma, 1962 [1953], págs. 117-119; “¿Existen los derechos naturales?, Revista de Estudios Públicos, 37, 1990 [1955]; y "Legal rights", op. cit., págs. 183-188. Algunos de los discípulos de Hart apoyan, en cambio, diferentes versiones de la teoría del interés; ver MacCormick, N., "Los derechos de los niños: una prueba de fuego para las teorías de los derechos", Anuario de Filosofia del Derecho, 5, Madrid, 1988 [1975] y Raz, J., La ética en el ámbito público, Barcelona, Gedisa, 2001 [1994], págs. 57-68. Para un resumen de la discusión de estas teorías ver Finnis, J., op. cit., págs. 231-233. Para una descripción de ambas teorías y asimismo de las teorías mixtas, Dabin, J., $E l$ derecho subjetivo, Granada, Comares, 2006, págs. 67-94.

${ }^{58}$ Atria, 2004a, pág. 23 y nota 23 en la misma página. 
toma de postura acerca del fundamento y no acerca del concepto de derecho subjetivo ${ }^{59}$.

Vinculada con la anterior, la segunda razón consiste en que Atria incurre en una contradicción cuando, al mismo tiempo que admite su aparente adhesión a una combinación de las teorías del interés y de la voluntad, parece creer que el concepto de derecho subjetivo que él emplea coincide con el concepto kelseniano de derecho subjetivo en sentido técnico, además de puntualizar que está utilizando el término potestad en el sentido de Hohfeld ${ }^{60}$. La contradicción se presenta porque tanto el análisis de Kelsen como el de Hohfeld de las posiciones jurídicas subjetivas conducen a rechazar cualquier teoría que, en lugar de poner el foco en la estructura o forma de estas posiciones, lo ponga en los bienes, valores o necesidades sustanciales que ellas protegen y justifican su otorgamiento ${ }^{61}$. Esta contradicción no es desde luego relevante por la autoridad de estos autores sino porque evidencia que Atria no solo cree que la estructura o forma de una posición jurídica excluye ciertos contenidos ${ }^{62}$, sino que también cree que ella está necesariamente vinculada con ciertos contenidos o, al menos, con una forma específica de determinación de contenidos ${ }^{63}$. Desde esta óptica, en la afirmación de que $x$ tiene derecho a $y$ puesto que $x$ tiene la potestad para decidir sobre la exigibilidad de $y$ estaría

${ }^{59}$ Arriagada, MB., "El concepto hohfeldiano de derecho subjetivo", Revista de Ciencias Sociales, 65, 2014.

${ }^{60} \mathrm{Ibidem}$, pág. 22 y nota 20 en la misma página.

${ }^{61}$ Ver Kelsen, H., Problemas capitales de la teoría jurídica, México D.F., Porrúa, 1987 [1923], págs. 510 y 539 y Hohfeld, W., op. cit., pág. 31. Otras aproximaciones estructurales se encuentran, por ejemplo, en Ferrajoli, L., "Derechos fundamentales" en De Cabo, A. y Pisarello, G. (eds.), Los fundamentos de los derechos fundamentales, Madrid, Trotta, 2007 [2001] y Diciotti, E., "Sulla distinzione tra diritti di libertà e diritti sociali: una prospettiva di filosofia analitica" Quaderni costituzionali / a. XXIV, 4, 2004.

${ }^{62}$ Atria, F., “¿Existen derechos sociales?”, pág. 42, op. cit. y Atria, F., "Réplica: derecho y política a propósito de los derechos sociales", pág.148, op. cit.

${ }^{63} \mathrm{Sin}$ referencia a la vida en comunidad; Atria, F., "¿Existen derechos sociales?", págs. 16-17, op. cit. y Atria, F., "Réplica: derecho y política a propósito de los derechos sociales”, págs. 148-149, op. cit. 
implicada la afirmación de que es lícito, bueno o justo que $x$ reciba $y$ conforme a determinado criterio de justicia.

Finalmente, la propuesta de Atria tiene el defecto de que, una vez establecido que los llamados derechos sociales no pueden expresarse en el lenguaje liberal de los derechos subjetivos, no aprovecha la oportunidad de avanzar en la dirección de mejorar la situación devaluada en la que se encuentran frente a los derechos liberales ${ }^{64}$. Las alternativas posibles parecen ser modificar el concepto de derecho subjetivo utilizado o el fundamento de los derechos sociales, pero Atria se limita a constatar la contradicción entre la forma jurídica de los derechos subjetivos y el contenido de los derechos sociales.

\section{La segunda propuesta de Atria}

Una década más tarde, Atria procura mejorar la situación de los derechos sociales sin renunciar a la comprensión socialista de los mismos ni a la crítica a la doctrina progresista. El camino escogido para ello es atribuir a los derechos sociales la misión de transformar el lenguaje que solo permite la expresión de los derechos civiles y políticos.

La nueva propuesta sobre las diferencias entre los derechos civiles y políticos y los derechos sociales puede sintetizarse en las siguientes tres tesis:

Primera tesis: en los derechos subjetivos pueden distinguirse dos caras y dos dimensiones.

El eje de la segunda propuesta de Atria es nuevamente el concepto de derecho subjetivo pero este ya no es entendido del mismo modo que hace una década. La modificación se realiza en dos pasos.

En el primer paso, Atria reitera que la característica principal de los derechos subjetivos es el poder de exigibilidad con que cuenta su

${ }^{64}$ Como subraya Cruz Parcero, Atria no consigue, ni siquiera a través de la reivindicación del concepto político de derecho subjetivo, mostrar una verdadera alternativa para el socialismo; Cruz Parcero, J., "Leones, lenguaje y derechos. Sobre la existencia de los derechos sociales. Réplica a Fernando Atria", pág. 93, op. cit. 
titular, pero a ello agrega que en los derechos subjetivos pueden distinguirse dos caras: una emancipatoria, representada por la negación de que un individuo pueda ser usado para beneficio de otro, y otra opresiva, representada por el hombre egoísta separado de otros hombres y de la comunidad ${ }^{65}$.

En el segundo paso, Atria argumenta que, en todos los derechos, pueden distinguirse dos dimensiones. Decir que alguien tiene un derecho a algo es, en principio, lo mismo que decir que: (i) es ilícito que no reciba aquello a lo que tiene derecho; y (ii) cuando es imposible satisfacer todos los derechos, la cuestión de cómo se distribuyen los recursos es una cuestión pública ${ }^{66}$.

Segunda tesis: los derechos sociales son diferentes a los derechos civiles y políticos porque son (i) injertos anómalos, (ii) una subversión del concepto de derecho subjetivo y (iii) un criterio de distribución diferente del mercado.

La idea de los derechos sociales como injertos anómalos aparece, en principio, como una nueva formulación de la idea de que ellos son diferentes a los derechos civiles y políticos porque no pueden expresarse en el lenguaje de los derechos subjetivos. Los derechos sociales habrían surgido como una forma de afirmar la importancia que - en términos de la justicia - tiene la idea de realización recíproca (en contra de una teoría liberal que ve la realización humana como algo fundamentalmente individual). Y así entendidos, solo podrían ser injertos anómalos en el derecho liberal, que precisamente se construye sobre la base de la idea de derecho subjetivo. De hecho, para ser injertos habrían tenido que formularse como derechos ${ }^{67}$.

${ }^{65}$ Siguiendo en esto a Proudhon, Atria suscribe la idea de que toda institución realmente existente tiene una cara emancipatoria y una cara opresiva; Atria, F., Veinte años después. Neoliberalismo con rostro humano, Santiago, Catalonia, 2013, págs. 147-148.

${ }^{66}$ Atria, F., Derechos sociales y educación. Un nuevo paradigma de lo público, págs. 57 y 66, op. cit. 
La novedad reside en que, según Atria, los derechos sociales dejarán de ser anómalos tanto si tienen éxito como si fracasan. En el primer caso, porque habrían sido capaces de transformar el derecho burgués, en el sentido de que, al menos, dejaría de ser un derecho construido sobre la base de la noción de derecho subjetivo, indiferente a la cooperación, y se construiría sobre la idea de deber recíproco, constitutiva de los derechos sociales. En el segundo caso, porque los derechos sociales habrían sido asimilados a las categorías burguesas, produciéndose la normalización del injerto extraño ${ }^{68}$.

La posibilidad de que los derechos sociales tengan éxito está conectada con la segunda idea que debe ser revisada. Como la noción misma de derechos sociales es, según Atria, una subversión del concepto de derecho subjetivo, su sentido es volver la teoría del derecho subjetivo en contra del derecho subjetivo. Por esta razón, sería crucial mantener la distinción entre estos derechos y los derechos liberales, aun cuando reconociendo el esfuerzo de la doctrina progresista, Atria admita que las diferencias que frecuentemente se esgrime que existen entre estas categorías de derechos son superficiales. Para fundamentar esta idea, Atria apela a la idea de que los derechos subjetivos tienen dos caras y argumenta que a la noción de derechos sociales correspondería la tarea de poner la teoría del derecho subjetivo en contra del derecho subjetivo, mediante la radicalización de su cara emancipatoria ${ }^{69}$.

Asumiendo que la denominación misma de derechos sociales muestra ya la subversión del concepto de derecho subjetivo, el primer paso habría sido sustituir la idea de señorío de la voluntad por la de la protección jurídica de un interés de un individuo. Este cambio en la comprensión habría hecho posible expresar en el lenguaje de los derechos la idea socialista de que hay ciertos intereses (aspectos del

${ }^{68}$ Atria, 2013, pág. 149 y 2014, págs. 46-47.

${ }^{69}$ Atria, 2014, págs. 38-43 y 45 y 2013, pág. 149. Siguiendo nuevamente a Proudhon, Atria cree que volver la teoría de la institución contra la institución significa utilizar una de sus caras para destacar los déficits de la otra, mostrando que el camino hacia el socialismo no pasa por la abolición de las instituciones liberales sino por la radicalización de su cara emancipatoria; Atria, 2013, págs. 147-148. 
bienestar) de cada uno que son responsabilidad de todos, volviendo la teoría del derecho subjetivo en contra del derecho subjetivo ${ }^{70}$.

Dado que los propios defensores de los derechos sociales estarían alentando su privatización o asimilación con los derechos liberales, el paso siguiente en la tarea de subvertir la idea de derechos sería usar la noción de derechos sociales para pensar instituciones que transformen el derecho burgués. La propuesta es que el caso de los derechos sociales mostraría que una idea individualista puede ser subvertida para transformarse en una idea socialista ${ }^{71}$.

La capacidad subversiva atribuida a los derechos sociales está, a su vez, conectada con la tercera idea que debe ser revisada: los derechos sociales como un criterio de distribución frente a la escasez diferente del mercado. Atria argumenta que como ellos expresan la idea de que hay ciertos aspectos del bienestar de cada uno que son responsabilidad de todos, porque son demasiado fundamentales en la vida realizada y la realización de uno es cuestión de todos, tales aspectos o intereses deberían ser descomodificados (removidos del mercado). Esto

${ }^{70}$ Atria, 2013, págs. 148-149. El paso desde la idea de derecho subjetivo como un señorío de la voluntad retratada, por ejemplo, por Hobbes, Spinoza e incluso por Kant a la idea de que se trata de un interés protegido por el derecho puede ser atribuido a Ihering; ver Hobbes, T., Leviatán, o la materia, forma y poder de una república eclesiástica civil, México D.F., Fondo de Cultura Económica, 1980 [1651], págs. 106 y 118-119 (Capítulos XIV y XV); Spinoza, B., Tratado teológico-politico, Madrid, Alianza, 2003 [1670], págs. 334-352 (Capítulo XVI); Kant, E., La metafisica de las costumbres, Madrid, Tecnos, 2005 [1797], págs. 41-42 (párrafo 232); e Ihering, R., La lucha por el derecho, Granada, Comares, 2011 [original de 1865], págs. 816 y 821 (Libro II, Segunda parte, Título I). Sobre la evolución del significado del derecho subjetivo ver, por ejemplo, los trabajos de Villey, M., op. cit. y Cruz Parcero, J., El lenguaje de los derechos, op. cit., pág. 25.

${ }^{71}$ Atria, 2013, págs. 149-151. La aplicación de esta idea al derecho a la educación se desarrolla en Atria, F., La mala educación, Santiago, Catalonia, 2012, págs. 85-104. La idea no es idéntica pero está emparentada con la cuestión que, en la discusión sostenida en 2004, Gargarella planteaba sobre la capacidad de los derechos, así como de otras creaciones humanas, de independizarse de las limitadas aspiraciones de sus creadores; Gargarella, 2004, págs. $62-63$. 
significa que el servicio que atiende un interés de este tipo se presta como un derecho, es decir, no solo bajo la condición de que quien lo requiera pueda pagar por él y, por tanto, que los recursos necesarios para satisfacer esos intereses deben ser distribuidos conforme a un criterio de ciudadanía: de forma igualitaria entre todos los que tienen derecho ${ }^{72}$.

Para fundamentar esta idea, Atria apela nuevamente al concepto de derecho subjetivo pero este ahora también es aplicable a los derechos sociales. Como en todos los derechos pueden distinguirse dos dimensiones, la prioridad entre ellas se invertiría cuando se trata de derechos sociales: "[L]a principal dimensión de decir que algo es un derecho social no es que de eso se desprenda una especificación precisa de qué es aquello a lo que cada uno tiene derecho, sino la publificación del problema de la distribución". Como consecuencia, los derechos sociales no podrían ser entendidos como derechos a prestaciones específicas y determinables ex-ante, sino como un criterio de distribución de los recursos disponibles que, a diferencia del criterio de mercado, descansa en el reconocimiento de la igualdad de todos ${ }^{73}$.

Desde esa perspectiva, los derechos sociales no representan una demanda que pueda ser satisfecha de una vez por todas y en términos universales (respondiendo qué aspecto del bienestar de otro es mi deber) sino una idea que provee un punto de referencia que nos guía lentamente en el aprendizaje de lo que nos debemos recíprocamente. Como en el régimen de lo público, lo que cada uno recibe es aquello a lo que tiene derecho como ciudadano, no es posible mejorar la situación individualmente (pagando más). En cambio, es necesario hacerlo políticamente (alineando el interés de uno con el interés de todos). El contenido de los derechos sociales, entendidos como derechos de ciudadanía, se desarrollaría, por tanto, en la historia y mediante

${ }^{72}$ Atria, 2013, págs. 34 y 152; Atria, 2014, págs. 51-52 y 57.

${ }^{73}$ Ibidem, págs. 55-61 y 65-66. 
decisiones políticas, enfrentando el hecho de la escasez con un criterio público, no privado ${ }^{74}$.

En este giro, Atria termina por concluir que, en cuanto expresan la idea de descomodificación, los derechos sociales están vinculados a la idea de libertad, y que el socialismo debe ser entendido como el legítimo heredero del liberalismo ${ }^{75}$. La clave del éxito de los derechos sociales podría sintetizarse en los siguientes términos:

Aunque la idea que fundamenta los derechos sociales es opuesta a la que fundamenta el derecho liberal, el lenguaje que utiliza para expresarla no es el de la oposición (el cual no podría ser entendido por la racionalidad del cuerpo receptor), sino el de la continuidad. Pero continuidad transformadora: los derechos sociales como la completa realización de lo que hay de importante en los derechos que son centrales para el derecho liberal (los derechos civiles y políticos) ${ }^{76}$.

A pesar de estos visibles cambios, Atria mantiene la idea de que los derechos sociales son diferentes porque no pueden ser identificados sin referencia a la comunidad, y asimismo por la forma en que se determina su contenido. Mientras los derechos de libertad negativa protegen intereses que pueden ser identificados en el estado de naturaleza, los

${ }^{74}$ Atria, F., Veinte años después. Neoliberalismo con rostro humano, págs. 159-187, op. cit. y Atria, F., Derechos sociales y educación. Un nuevo paradigma de lo público, págs. 65 y 69-77, op. cit.

${ }^{75}$ Atria, F., Veinte años después. Neoliberalismo con rostro humano, págs. 92 y 159, op. cit. Dado que el mercado no sería únicamente un criterio de distribución (dimensión opresiva), sino también la forma institucional de un espacio de intercambio no forzado (dimensión emancipatoria), el éxito de los derechos sociales mostraría que la dimensión emancipatoria del mercado puede ser igual para todos y no solo para los privilegiados y, en esa medida, que estos derechos están dirigidos a asegurar la libertad para todos; ibidem, págs. 152-159.

${ }^{76}$ De acuerdo con Atria, esta es la importancia de la afirmación de Marshall según la cual los derechos (civiles, políticos y sociales) aparecen progresivamente en la historia, de suerte que cada paso desarrolla más plenamente el sentido del paso anterior, la idea de ciudadanía; Atria, F., Derechos sociales y educación. Un nuevo paradigma de lo público, pág. 46, op. cit. 
intereses protegidos por los derechos sociales no pueden ser identificados del mismo modo puesto que, en tanto derechos del ciudadano situado, suponen el vínculo de ciudadanía. Consiguientemente, la especificación completa del aspecto activo de los derechos de libertad negativa es inmediatamente una especificación de su aspecto pasivo (quién tiene qué deber), puesto que se trata de derechos naturales y su sujeto pasivo es universal. En contraste, una especificación del aspecto activo de los derechos sociales (del interés al que el derecho sirve) no sería suficiente para especificar su aspecto pasivo (un deber de proteger ese interés) ${ }^{77}$.

Tercera tesis: el fracaso de los derechos sociales es la neutralización de su capacidad subversiva.

Dependiendo de cómo sea salvada la brecha entre el interés del titular y el deber, hay, según Atria, dos maneras diferentes de entender a los derechos sociales que, básica y respectivamente, corresponden a las comprensiones socialista y liberal analizadas en su primera propuesta: (i) T.H. Marshall entiende a los derechos sociales como la sustancia de la ciudadanía pues, al contener la idea de que hay ciertos aspectos del bienestar de cada uno que son responsabilidad de todos, descansan en la idea de realización recíproca y no pueden entenderse como indiferentes a la cooperación; y (ii) la teoría contractualista los entiende como una protección contra la pobreza y, este sentido, como una forma de asegurar que el pobre esté vinculado por el contrato y sujeto entonces a la autoridad del derecho y del Estado ${ }^{78}$.

La primera comprensión, ya revisada es, según Atria, la que conduce al éxito de los derechos sociales. La segunda conduce, en cambio, a su fracaso porque, desde esa perspectiva, no son entendidos como derechos de ciudadanía sino como derechos a un mínimo dirigido a satisfacer necesidades básicas.

Como en la visión contractualista lo políticamente fundamental es la protección de intereses que pueden ser identificados en el

${ }^{77}$ Ibídem, págs. 48 y 51-52.

${ }^{78}$ Ibídem, págs. 48-52. 
estado de naturaleza, la capacidad subversiva de los derechos sociales resulta neutralizada como consecuencia de su secuestro por las categorías burguesas. Al ser convertidos en algo que pueda ser protegido y exigido en términos individualistas ellos dejan de ser derechos sociales porque ya no expresan la idea socialista de realización recíproca y de que hay aspectos del bienestar que son responsabilidad de todos, sino la idea individualista del hombre egoísta y de que es necesario asegurarle a todos un mínimo para justificar su obligación de someterse al derecho. El potencial transformador de los derechos sociales es neutralizado como consecuencia del exceso de entusiasmo de sus defensores progresistas que erradamente creen que la principal dimensión que se juega en su reconocimiento es su exigibilidad judicial ${ }^{79}$.

\section{Las fortalezas y limitaciones de la segunda propuesta de Atria}

La segunda propuesta de Atria no es otra cosa que un intento por mejorar la situación devaluada de los derechos sociales sin renunciar a su comprensión socialista ni a la crítica a la doctrina progresista, y allí parece encontrarse su principal mérito. En efecto, aunque en contra de su propuesta se puede argumentar, como se hizo en el año 2004, que la concepción socialista no es la única fuente a partir de la cual puede ofrecerse una justificación filosófico-política de los derechos sociales $^{80}$, Atria prefiere mantener la comprensión, situada en el nivel

${ }^{79}$ Atria, F., Derechos sociales y educación. Un nuevo paradigma de lo público, págs. 52-53 y 65, op. cit. y Atria, F., Veinte años después. Neoliberalismo con rostro humano, págs. 149-151 y 180, op. cit.

${ }^{80}$ Ver Bernal, C., "Fundamento, concepto y estructura de los derechos sociales. Una crítica a ‘Existen los derechos sociales?' de Fernando Atria”, pág. 108, op. cit., quien afirma que también puede invocarse la concepción del Estado Social de Derecho que, al no oponerse como el socialismo al Estado liberal, no niega de ningún modo las libertades; en el mismo sentido, ver por ejemplo Peces-Barba, G., "Los derechos sociales: apuntes políticos y jurídicos," en Zapatero, V. y Garrido, M.I. (eds.), Los derechos sociales como una exigencia de la justicia, Madrid, Cuadernos democracia y derechos hu- 
Derechos sociales y liberales. Un balance sobre la discusión de 2004

de la filosofía política, según la cual los derechos sociales son situaciones de bienestar material en las que, en interés de todos los individuos de la comunidad, cualquier individuo debiera encontrarse.

La consistencia de Atria en este punto permite, al menos en principio, inferir que su afirmación de que los derechos sociales son (i) injertos anómalos que pueden dejar de ser anómalos, (ii) una subversión del concepto de derecho subjetivo, y (iii) un criterio de distribución diferente del mercado, solo da cuenta de un cambio en el modo de entender los derechos civiles y políticos y, por tanto, de definir el concepto de derecho subjetivo. Esta parece ser la estrategia dirigida a mejorar la situación de los derechos sociales.

El primer paso en esta dirección sería matizar la comprensión de los derechos civiles y políticos como equivalentes a los derechos subjetivos privados ${ }^{81}$ distinguiendo, en los derechos subjetivos, dos diferentes caras (una opresiva y una emancipatoria) ${ }^{82}$. Este cambio permite

manos, Universidad de Alcalá, 2009, pág. 19. A esto conviene añadir que, incluso en el esquema del Estado Social de Derecho, los derechos sociales pueden fundamentarse de forma independiente o como medios para garantizar el ejercicio real de las libertades; Bernal, C., "Fundamento, concepto y estructura de los derechos sociales. Una crítica a '¿Existen los derechos sociales?' de Fernando Atria”, pág. 109, op. cit. Ejemplos de la primera forma pueden encontrarse en Tugendhat, E., Lecciones de ética, Barcelona, Gedisa, 2010 [1993], pág. 335; Garzón Valdés, E., "Cinco consideraciones acerca de la concepción de los derechos sociales de Robert Alexy", en Alexy R. et.al., Derechos sociales y ponderación, Madrid, Fundación Coloquio Jurídico Europeo, 2007, págs. 156-157 y Pisarello, G., Los derechos sociales y sus garantías. Elementos para una reconstrucción, Madrid, Trotta, 2007, pág. 38, entre otros. Respecto de la segunda forma puede verse, por ejemplo, Alexy, R., op. cit., págs. 446-453 y ss; García de Enterría, E., La Constitución como norma y el Tribunal Constitucional, Madrid, Civitas, 1985, págs. 92-93; Bobbio, N., Teoría general de la política, Madrid, Trotta, 2009 [1999], págs. 113-114, 540541, 545 y Peces-Barba., "Los derechos económicos sociales y culturales: apunte para su formación histórica y su concepto", en Derechos sociales y positivismo jurídico, Madrid, Dykinson, 1999, págs. 57-58.

${ }^{81}$ Atria, F., “¿Existen derechos sociales?”, págs. 51-52, op. cit.

${ }^{82}$ Atria, F., Veinte años después. Neoliberalismo con rostro humano, págs. 147-148, op. cit. 
redirigir la crítica hacia el neoliberalismo ${ }^{83}$, pues solo dejando a salvo al liberalismo resulta posible asignar a los derechos sociales la tarea de transformar el derecho liberal.

El paso siguiente parece consistir en discutir si los derechos sociales serán o no capaces de subvertir el concepto de derecho subjetivo, y la conclusión es, en principio, positiva puesto que Atria cree posible pensar en un concepto que también sea aplicable a los derechos sociales. Desde esta nueva mirada, tener un derecho no solo significa que es ilícito no recibir aquello a lo que se tiene derecho (primera dimensión) sino, además, que cuando es imposible satisfacer todos los derechos, la cuestión de cómo se distribuyen los recursos es una cuestión pública (segunda dimensión) ${ }^{84}$. A través de este cambio, Atria focaliza su crítica en el contractualismo, cuya comprensión de la asociación política no dejaría espacio para los auténticos derechos sociales ${ }^{85}$.

E1 primer problema de la segunda propuesta de Atria es que ella no clarifica si para afirmar que alguien tiene un derecho (de cualquier clase) sigue siendo necesaria la potestad de decidir sobre la exigibilidad de la obligación correlativa. Como hemos visto, la diferencia entre los derechos de libertad negativa y los derechos sociales reside solamente en la prioridad que corresponde a cada una de las dimensiones presentes en los derechos. Así, mientras de la ilicitud de la vulneración de un derecho del primer tipo se deprende una especificación completa de su contenido pasivo, de la ilicitud de la vulneración de un derecho del segundo tipo no se desprende dicha especificación.

La formulación del concepto de derecho subjetivo admite entonces dos interpretaciones.

La primera es que para afirmar que $x$ tiene derecho a $y$ no es necesario que $x$ tenga la potestad de decidir sobre la exigibilidad de $y$. En

${ }^{83}$ Atria, de hecho, se refiere a las razones o causas que explicarían la alianza entre neoliberalismo y conservadurismo, concluyendo que el primero es conservador en cuanto, al igual que el segundo, acepta la desigualdad como un hecho natural; ibídem, pág. 92 y ss.

${ }^{84}$ Atria, F., Derechos sociales y educación. Un nuevo paradigma de lo público, págs. 57 y 66 , op. cit. 
este caso, el concepto de derecho subjetivo habría sido claramente modificado, con la sorprendente consecuencia de que el contenido de este concepto (las razones que Atria esgrime para justificar su otorgamiento) es compatible con la estructura del concepto kelseniano de derecho reflejo. La cuestión es paradojal porque este concepto es precisamente el que se utiliza para argumentar que la consideración de los derechos sociales como auténticos derechos no depende de su garantía judicial, con lo cual la postura de Atria terminaría confluyendo con el punto de partida de la doctrina progresista, esto es, antes de su alegato en favor de la justiciabilidad de los derechos sociales.

La segunda interpretación es que en la afirmación de que es ilícito que $x$ no reciba $y$ (aquello a lo que tiene derecho) está implicada la afirmación de que $x$ tiene la potestad de decidir sobre la exigibilidad de $y$. En este caso, el concepto de derecho subjetivo no habría cambiado pero sí habría tenido que cambiar el fundamento de los derechos sociales, cuestión que Atria se resiste a aceptar.

A favor de la primera interpretación, puede decirse que el empeño de Atria ha sido mostrar que los derechos sociales tienen justamente la misión de subvertir el concepto de derecho subjetivo. A favor de la segunda interpretación, se puede decir que Atria afirma que para que los derechos sociales puedan ser judicialmente exigibles es necesario leer en su aspecto activo una especificación suficientemente precisa del deber que ellos imponen y que el contenido de los derechos sociales se desarrolla en la historia, de modo que la sola consideración de su aspecto activo no es suficiente para determinar su contenido pasivo ${ }^{86}$. De lo dicho parece, entonces, deprenderse que, una vez determinado de este modo su contenido, los derechos sociales podrían llegar a ser judicialmente exigibles.

El segundo problema en esta propuesta de Atria es que ella no aclara por qué el contractualismo es siempre necesario para la explicación de los derechos civiles y políticos. El concepto de derecho reflejo y el de derecho subjetivo en sentido técnico son compatibles con diversas teorías sobre el fundamento para conferir derechos, pues 
se trata de posiciones subjetivas fundamentadas en normas jurídicas. Pero Atria continúa asumiendo que los derechos civiles son concebidos como derechos naturales porque para especificar su contenido pasivo es suficiente atender a la posición del individuo aislado y, por lo mismo, también asume que solo el contenido de los derechos sociales se desarrolla en la historia y mediante un criterio público de distribución, en circunstancias en las que es muy discutible que no pueda decirse lo mismo de los derechos civiles y políticos. Piénsese, por ejemplo, en cómo ha ido variando el contenido del derecho a voto o de cualquiera de las llamadas libertades civiles. ¿Acaso no se emplea un criterio público de distribución cuando se perfilan los límites de estos derechos, dado que no es posible su completa satisfacción?

En la discusión del año 2004, Bernal apuntaba que la afirmación de que los derechos de primera generación pueden ser concebidos como derechos naturales no parece plausible. Al respecto esgrimía que ellos también suponen a un individuo situado porque no sería posible especificar el contenido pasivo de una libertad sin presuponer la existencia de otros individuos capaces de vulnerarla ${ }^{87}$. Atria respondía que Bernal estaba confundiendo la cuestión relativa a las condiciones del discurso moral y jurídico con la cuestión relativa a la especificación de los conceptos jurídicos, específicamente el concepto de derechos. Su argumento era que para poder hablar de la aplicación jurídica del concepto de derecho subjetivo, este debe ser susceptible de ser aplicado mediante una forma de razonamiento que pueda ser entendida como jurídica, es decir, que tenga una cierta autonomía respecto del razonamiento moral y político. A su parecer, esto no es posible, no porque los derechos sociales sean - a diferencia de los de primera generación - indeterminados en su contenido, sino porque lo que la positivización de los derechos sociales deja abierto es precisamente la decisión política que un juez podría aplicar en tanto juez. Por lo mismo, sostiene que la concepción de los derechos sociales como

${ }^{87}$ Bernal, C., "Fundamento, concepto y estructura de los derechos sociales. Una crítica a '¿Existen los derechos sociales?' de Fernando Atria”, pág. 100 (nota 11 de ese trabajo), op. cit. 
derechos prima facie y el principio de proporcionalidad defendidos por Bernal no dejan espacio para la distinción entre el razonamiento jurídico y el moral o político ${ }^{88}$.

A esto puede responderse que, en otro de sus trabajos, Atria admite que frente a todas las disposiciones constitucionales sobre derechos fundamentales, y no solo frente a las referidas a derechos sociales, los jueces no podrían ser sino activistas (liberales, conservadores, socialistas, etc.) disfrazados de jueces, pues se trata de normas cuya aplicación no adjudica realmente el conflicto ${ }^{89}$. Un juez no podría entonces aplicar estas disposiciones "en tanto juez" y, en consecuencia, no existiría la diferencia entre derechos sociales y civiles y políticos alegada por Atria, puesto que la aplicación de estos últimos tampoco dejaría espacio para la distinción entre el razonamiento jurídico y el moral o político.

Por otra parte, como Atria reconoce que la cuestión de la distribución frente a recursos escasos (la dimensión según la cual cuando es imposible satisfacer todos los derechos, la cuestión de cómo se distribuyen los recursos es una cuestión pública) no es algo propio de los derechos sociales sino de los derechos en genera $1^{90}$, no se logra comprender por qué el contractualismo sigue siendo el único fundamento posible de los derechos liberales.

Dado que es discutible que los llamados derechos civiles y, sobre todo, los llamados derechos políticos puedan explicarse del mismo modo que los derechos subjetivos privados ${ }^{91}$, Atria parece intuir parte

${ }^{88}$ Atria, F., "Réplica: derecho y política a propósito de los derechos sociales", págs. 149-151, op. cit.

${ }^{89}$ Atria, F., "El derecho y la contingencia de lo político", Revista Derecho y Humanidades, 11, 2005, págs. 27-29.

${ }^{90}$ Atria, F., Derechos sociales y educación. Un nuevo paradigma de lo público, págs. 57-61 y 65-66, op. cit.

${ }^{91} \mathrm{La}$ común agrupación de los derechos civiles y los derechos políticos bajo una misma categoría analítica supone, cuando menos, poner entre paréntesis el papel que estos últimos tienen en la constitución de la voluntad estatal; sobre este papel, ver por ejemplo Kelsen, H., Teoría pura, op. cit., págs. 150152; Hesse, C., op. cit., págs. 90-91 y Jellinek, G., Teoría general del Estado, (2. ${ }^{a}$ edición), Buenos Aires, Albatros, 1954 [1911], págs. 315-318. Para algunos autores la referida agrupación no solo es atacable por su déficit explicativo 
del problema desde el momento en que omite referirse a los derechos políticos, y menciona solamente los derechos civiles $^{92}$ que ahora también denomina "derechos de libertad negativa"93. Sin embargo, además de no dar razones para justificar este cambio, tampoco descarta fundadamente, por ejemplo, la posibilidad de vincular los derechos civiles con el interés general ${ }^{94}$, alternativa que claramente se opone a la idea del hombre separado de la comunidad, que Atria considera que forma parte del concepto de derecho subjetivo.

Cruz Parcero parece sugerir lo mismo cuando sostiene que no se justifica la visión de Atria según la cual todo reclamo de un individuo es un reclamo egoísta que se opone al interés general. A su parecer, cuando se dice, por ejemplo, que todos tienen derecho a la vida, a la libertad o a la integridad no se está haciendo un juicio que ponga por encima los intereses individuales a los colectivos sino afirmando que el interés general o de todos es que ciertos bienes estén protegidos para todos y cada uno de los miembros de la sociedad ${ }^{95}$.

sino también por ser derechamente problemática; por ejemplo, Berlin, I., "Dos conceptos de libertad" en Sobre la libertad, Madrid, Alianza, 2004 [original de 1958], págs. 216 y 249; Ruiz Miguel, A., Una filosofia del derecho en modelos históricos. De la antigüedad a los inicios del constitucionalismo, Madrid, Trotta, 2002, págs. 269 y 281-282; Bayón, J.C., "Democracia y Derechos: problemas de fundamentación del constitucionalismo", en Constitución y derechos fundamentales, Madrid, Centro de Estudios Políticos y Constitucionales, 2004, pág. 73 y ss; y Waldron, J., Derecho y desacuerdos, Madrid, Marcial Pons, 2005 [1999]. Sobre la razón que, en principio, justifica la agrupación de los llamados derechos políticos y los llamados derechos civiles bajo una misma categoría analítica, ver por ejemplo, Habermas, J., Teoría y praxis. Estudios de filosofía social, Madrid, Tecnos, 2008 [1963], págs. 148-149.

${ }^{92}$ Atria, F., Derechos sociales y educación. Un nuevo paradigma de lo público, págs. 49 y 53 , op.cit.

${ }^{93}$ Ibídem, pág. 48.

${ }^{94}$ En este sentido, por ejemplo, Raz, J., op. cit., págs. 57-68, según quien la protección de muchos de nuestros más apreciados derechos civiles y políticos en las democracias liberales se justifica por el hecho de que están al servicio del bien común o general.

${ }^{95}$ Cruz Parcero, J., "Leones, lenguaje y derechos. Sobre la existencia de los derechos sociales. Réplica a Fernando Atria", págs. 79-80, op. cit. 
La crítica es interesante pero, a mi juicio, no alcanza el punto realmente importante puesto que se circunscribe a rechazar el uso que hacía Atria de lo que Cruz Parcero llama el modelo relacional simple para reivindicar, en cambio, la idea de los derechos subjetivos "como un todo" 96 .

El problema de esta lectura, así como el de cualquiera que entienda los derechos subjetivos como un conjunto de posiciones jurídicas subjetivas activas ${ }^{97}$, es que conduce a confundir las posiciones jurídicas subjetivas conferidas por el derecho objetivo para la protección de bienes con los bienes objeto de esa protección ${ }^{98}$. El propio Atria advierte que el concepto de derecho "como un todo" no es otra cosa que el concepto pre-moderno del ius, es decir, lo que corresponde en justicia o lo que es bueno o valioso, que constituye premisa y no conclusión del razonamiento jurídico ${ }^{99}$. Pero lo que Atria no nota es que, cuando él afirma que los derechos de libertad negativa son concebidos como derechos naturales porque para especificar su contenido pasivo es suficiente atender a la posición del individuo aislado, también está confundiendo posiciones jurídicas conferidas por normas del derecho objetivo con los bienes que son objeto de esa protección.

$\mathrm{Su}$ error es asumir que la estructura de las posiciones jurídicas subjetivas está necesariamente vinculada con las razones que justifican (o pueden justificar) su otorgamiento. $\mathrm{Y}$ su mayor desacierto es haber perdido la oportunidad de ensayar una lectura diferente de los derechos civiles y políticos, atendido que ellos funcionan como el punto de referencia para juzgar la situación de los derechos sociales.

${ }^{96}$ Ibídem, págs. 76-80 y El lenguaje de los derechos, op. cit., págs. 36-38.

${ }^{97}$ Ver por ejemplo, Laporta, F., "Sobre el concepto de derechos humanos", Doxa, 4, 1987, págs. 23-30, Hierro, L., "¿Qué derechos tenemos?", Doxa, 23, 2000, págs. 355-356, Alexy, R., op. cit., págs. 214-218 y Diciotti, E., op. cit., págs. 738-739.

${ }^{98}$ Ver Arriagada, MB., "Los derechos sociales: únicos derechos fundamentales", op. cit., págs. 68-70.

${ }^{99}$ Atria, F., "Réplica: derecho y política a propósito de los derechos sociales", págs. 165-173, op. cit. (ver también nota 23 en ese trabajo). 
Atria tiene razón al decir que la situación devaluada en la que se encuentran los derechos sociales no puede solucionarse procurando su equiparación con los derechos civiles y políticos. Pero a esto debe añadirse que la situación de los primeros no puede siquiera calibrarse mediante su comparación con los segundos. La comprensión generalizada, compartida por Atria, de los derechos civiles y políticos como derechos subjetivos en sentido técnico que reflejan obligaciones que otros deben cumplir pasa por alto su significado político ${ }^{100} \mathrm{y}$, con ello, el importante papel que estas posiciones jurídicas subjetivas tienen en las decisiones acerca de lo que cuenta y no cuenta como derecho. Esta omisión es, en mi opinión, la razón por la cual Fernando Atria no ha conseguido avanzar más en la tarea de resolver la tensión entre el concepto y el fundamento de los derechos fundamentales y la de mejorar la situación de los derechos sociales.

\section{Consideraciones finales}

Concluyo este trabajo solamente enunciando las principales tesis ${ }^{101}$ que, en mi opinión, permiten una mejor comprensión de los derechos civiles y políticos y, por tanto, un progreso significativo en las tareas recién mencionadas.

${ }^{100}$ Piénsese en el papel de la jurisdicción constitucional y, sobre ello, ver Kelsen, H., De la esencia y valor de la democracia, Oviedo, KRK Ediciones, 2009 [1929], págs. 139-142 y 227-228; "¿Quién debe ser el defensor de la Constitución?", en Schmitt, C. y Kelsen, H. La polémica Schmitt/Kelsen sobre la justicia constitucional: El defensor de la Constitución versus ¿Quién debe ser el defensor de la Constitución?, Madrid, Tecnos, 2009 [1931], págs. 292-293, 305-308, 311-314 y 324-325 y nota 11 del mismo trabajo; y Teoría pura, op. cit., págs. 150-161 y 232-234.

${ }^{101}$ He desarrollado estas tesis en Arriagada, M.B., "Las Cortes Constitucionales frente a los derechos civiles y políticos", Revista española de derecho constitucional, de próxima aparición. 
Derechos sociales y liberales. Un balance sobre la discusión de 2004

Si se distinguen correctamente las normas regulativas de las normas de competencia ${ }^{102}$ y los actos materiales de los actos normati$\operatorname{vos}^{103}$, se pueden fundar las siguientes tesis:

(i) Los llamados derechos políticos no son derechos subjetivos que reflejan obligaciones de realizar o abstenerse de realizar determinados actos materiales porque no se fundamentan en normas regulativas sino en normas de competencia que, en los órdenes jurídicos democráticos, confieren a los individuos potestades para participar en las decisiones públicas sobre lo que cuenta como derecho ${ }^{104}$.

(ii) Como en los sistemas democráticos los órganos del Estado son competentes para producir normas que obligan a los sujetos sometidos al derecho precisamente porque dichos órganos son elegidos a través del sufragio de los titulares de los denominados derechos políticos, estos son una condición de la validez de las normas jurídicas producidas por las autoridades públicas y, vistos así, no son comparables ni equiparables con los llamados derechos sociales.

(iii) Las disposiciones normativas que consagran los denominados derechos civiles expresan dos tipos de normas jurídicas

${ }^{102}$ Sobre esto, ver especialmente Hart, H.L.A., El concepto de derecho, Buenos Aires, Abeledo Perrot, 2009 [1961], págs. 43-44; Bulygin, E., "Sobre las normas de competencia," en Alchourrón, C. y Bulygin, E., Análisis lógico y derecho, Madrid, Centro de Estudios Políticos y Constitucionales, 1991 [1988], págs.487-489 y 495-496; y Alchourrón, C. y Bulygin, E., "Definiciones y normas," en Análisis lógico y derecho, Madrid, Centro de Estudios Políticos y Constitucionales, 1991 [1983], pág. 462.

${ }^{103}$ Ferrajoli, L., Principia iuris. Teoría del derecho y de la democracia, Madrid, Trotta, 2011 [2007], págs. 464-465. En términos searlianos, los actos materiales serían hechos brutos, su existencia no depende lógicamente de la existencia de ninguna regla; y los actos normativos serían hechos institucionales, su existencia es lógicamente dependiente de la existencia de reglas constitutivas; Searle, J., Actos de habla. Ensayo de Filosofia del Lenguaje, Madrid, Cátedra, 2007 [1969], págs. 58-61 y La construcción de la realidad social, Barcelona, Paidós, 1997 [1995], págs. 44-46.

${ }^{104}$ Kelsen, H., Teoría pura, op. cit., págs. 150-151. 
que, además de ser diferentes e irreductibles, no se refieren al mismo tipo de conducta: (a) Normas regulativas que confieren a los individuos derechos subjetivos, en cuanto imponen obligaciones de abstención de cuyo cumplimiento depende la licitud de actuaciones materiales; y (b) Fragmentos de normas de competencia que confieren a los individuos potestades de participación política cuyo ejercicio condiciona la validez general o particular de las normas jurídicas producidas por las autoridades públicas y, por tanto, las decisiones sobre lo que no cuenta como derecho.

(iv)Los llamados derechos civiles tienen dos diferentes significados: (a) En cuanto auténticos derechos subjetivos habitualmente provistos de garantía judicial, no son equiparables con los llamados derechos políticos puesto que son derechos subjetivos en sentido técnico que, amparados directamente por las cortes constitucionales, sirven a la función conservadora del derecho y, por tanto, son condición de posibilidad del Estado de Derecho; y (b) En cuanto potestades de participación política, son equiparables con los llamados derechos políticos constitutivos de la democracia, puesto que sirven a la función de creación y transformación del derecho en el mismo proceso en el cual las cortes constitucionales actúan como legisladores negativos, sin proteger directamente derechos subjetivos.

(v) Solo en cuanto son entendidos como derechos subjetivos que reflejan obligaciones de abstención de cuyo cumplimiento depende la licitud de actuaciones materiales, los llamados derechos civiles sirven como referencia para calibrar la situación de los derechos sociales, entendidos estos como derechos subjetivos que reflejan obligaciones de prestación cuyo incumplimiento determina la ilicitud de la abstención correspondiente. Mientras los primeros suelen ser derechos subjetivos judicialmente garantizados, los segundos son, por la común ausencia de esta garantía, derechos subjetivos devaluados. 
Derechos sociales y liberales. Un balance sobre la discusión de 2004

\section{Bibliografía}

Abramovich, V. y Courtis, C., Los derechos sociales como derechos exigibles, Madrid, Trotta, 2004.

Alchourrón, C. y Bulygin, E., "Definiciones y normas", en Alchourrón, C., y Bulygin, E., Análisis lógico y derecho, Madrid, Centro de Estudios Políticos y Constitucionales, 1991 [original de 1983], págs. 439-463.

Alexy, R., Teoría de los derechos fundamentales, Madrid, Centro de Estudios Políticos y Constitucionales, 2007 [original de 1984]. Arriagada, MB.,

.- "Los derechos sociales: únicos derechos fundamentales", en Aguilar, G. (ed.), Derechos económicos, sociales y culturales en el orden constitucional chileno, Santiago, Librotecnia, 2012, págs. 61-91.

.- "El concepto hohfeldiano de derecho subjetivo", Revista de Ciencias Sociales, 65, 2014, págs. 13-45.

.- "Las Cortes Constitucionales frente a los derechos civiles y políticos", Revista española de derecho constitucional (de próxima aparición).

Atria, F.,

.- “¿Existen derechos sociales?”, Doxa 4, 2004, págs. 15-59.

-- "Réplica: derecho y política a propósito de los derechos sociales", Discusiones, 4, 2004, págs. 145-176.

-- El derecho y la contingencia de lo político", Revista Derecho y Humanidades, 11, 2005, págs. 19-39.

.- La mala educación, Santiago, Catalonia, 2012.

-- Veinte años después. Neoliberalismo con rostro humano, Santiago, Catalonia, 2013.

-- Derechos sociales y educación. Un nuevo paradigma de lo público, Santiago, LOM, 2014.

Atria, F., Larraín, G., Benavente, J., Couso, J., y Joignant, A., El otro modelo. Del orden neoliberal al régimen de lo público, Santiago, Debate, 2013.

Bastida, F., "¿Son los derechos sociales derechos fundamentales? Por una concepción normativa de la fundamentalidad de los derechos", 
en Alexy, R. et.al. Derechos sociales y ponderación, Madrid, Fundación Coloquio Jurídico Europeo, 2007, págs. 103-149.

Bayón, J.C., "Democracia y Derechos: problemas de fundamentación del constitucionalismo", en Constitución y derechos fundamentales, Madrid, Centro de Estudios Políticos y Constitucionales, 2004. Berlin, I., "Dos conceptos de libertad" en Sobre la libertad, Madrid, Alianza, 2004 [original de 1958], págs. 205-255.

Bernal, C., "Fundamento, concepto y estructura de los derechos sociales. Una crítica a ‘Existen los derechos sociales?' de Fernando Atria”, Discusiones, 4, 2004, págs. 99-144.

Bobbio, N.,

-- Derecha e izquierda. Razones y significados de una distinción politica, Madrid, Taurus, 1996.

-- Teoría general de la política, Madrid, Trotta, 2009 [original de 1999]. Böckenförde, E., Escritos sobre Derechos Fundamentales, Baden-Baden, Nomos Verlagsgessellschaft, 2001 [original de 1993].

Bonazzi, T., "Conservadurismo", en Bobbio, N., Mateucci, N., y Pasquino, G., Diccionario de politica, México D.F., Siglo XXI, 2007 [original de 1983], págs. 318-323.

Bulygin, E.,

.- "Sobre las normas de competencia", en Alchourrón, C. Bulygin, E., Análisis lógico y derecho, Madrid, Centro de Estudios Políticos y Constitucionales, 1991 [original de 1988], págs. 485-498.

.- "Raz y la teoría del derecho. Comentarios sobre '¿Puede haber una teoría del derecho?' de Joseph Raz”, en Raz, J., Alexy, R. y Bulygin, E., Una discusión sobre la teoría del derecho, Madrid, Marcial Pons, 2007, págs. 99-110.

Carbonell, M., "Eficacia de la Constitución y derechos sociales: esbozo de algunos problemas", Revista de Derecho Público Universidad de Chile, volumen 70, 2008, págs. 23-47.

Carrió, G., "Nota preliminar", en Hohfeld, W. Conceptos jurídicos fundamentales, México D.F., Fontamara, 1992 [original de 1913], págs. 7-21.

Cruz Parcero, J., 
.- "Leones, lenguaje y derechos. Sobre la existencia de los derechos sociales. Réplica a Fernando Atria”, Discusiones, 4, 2004, págs. 71-98.

.- El lenguaje de los derechos. Ensayo para una teoría estructural de los derechos, Madrid, Trotta, 2007.

Dabin, J., El derecho subjetivo, Granada, Comares, 2006.

De Cabo, A., y Pisarello, G., "Ferrajoli y el debate sobre los derechos fundamentales", en De Cabo, A y Pisarello, G (eds.), Los fundamentos de los derechos fundamentales, Madrid, Trotta, 2007 [original de 2001], págs. 9-17.

Diciotti, E., "Sulla distinzione tra diritti di libertà e diritti sociali: una prospettiva di filosofia analitica", Quaderni costituzionali / a. XXIV, 4, 2004, págs. 733-762.

Dworkin, R., El imperio de la justicia, Barcelona, Gedisa, 1998 [original de 1986].

Escudero, R., "Estudio preliminar", en Comanducci, P., Hacia una teoría analítica del derecho. Ensayos escogidos, Madrid, Centro de Estudios Políticos y Constitucionales, 2010.

Ferrajoli, L.,

.- "Derechos fundamentales", en De Cabo, A. y Pisarello, G. (eds.), Los fundamentos de los derechos fundamentales, Madrid, Trotta, 2007 [original de 2001], págs. 19-56.

- Principia iuris. Teoría del derecho y de la democracia, Madrid, Trotta, 2011 [original de 2007].

Finnis, J., Ley natural y derechos naturales, Buenos Aires, Abeledo Perrot, 2000 [original de 1980].

García de Enterría, E., La Constitución como norma y el Tribunal Constitucional, Madrid, Civitas, 1985.

Gargarella, R., "Derecho y disociación. Un comentario a '¿Existen los derechos sociales?' de Fernando Atria,” Discusiones, 4, 2004, págs. 61-70.

Garzón Valdés, E., "Cinco consideraciones acerca de la concepción de los derechos sociales de Robert Alexy", en Alexy R. et.al., Derechos sociales y ponderación, Madrid, Fundación Coloquio Jurídico Europeo, 2007, págs. 151-162. 
Grocio, H., Del derecho de presa y Del derecho de la guerra y de la paz. Textos de las obras "De iure Predae" y "De Iure Belli ac Pacis", Madrid, Centro de Estudios Constitucionales 1987 [original de 1625].

Guastini, R., Distinguiendo. Estudios de teoría y metateoría del derecho, Barcelona, Gedisa, 1999 [original de 1996].

Habermas, J., Teoría y praxis. Estudios de filosofía social, Madrid, Tecnos, 2008 [original de 1963].

Hart, H.L.A.,

.- "Definición y teoría en la ciencia judicial", en Derecho y moral. Contribuciones a su análisis, Buenos Aires, Depalma, 1962 [original de 1953], págs. 93-130.

.- El concepto de derecho, Buenos Aires, Abeledo Perrot, 2009 [original de 1961].

.- "Legal Rights", en Essays on Bentham. Studies in Jurisprudence and Political Theory, New York, Oxford University Press, 1982.

.- “¿Existen los derechos naturales?”, en Revista de Estudios Públicos, No37, 1990 [original de 1955], págs. 4-61.

Hesse, C., "Significado de los derechos fundamentales", en Benda et.al., Manual de Derecho Constitucional, Madrid, Evap-Marcial Pons, [original de 1994].

Hierro, L.,

.- “¿Qué derechos tenemos?”, Doxa, 23, 2000, pág. 351-375.

-- "Los derechos económico-sociales en la teoría de los derechos de Robert Alexy", en Alexy, R. y otros, Derechos sociales y ponderación, Madrid, Fundación Coloquio Jurídico Europeo, 2007, págs. 163-222.

Hobbes, T., Leviatán, o la materia, forma y poder de una república eclesiástica civil, México D.F., Fondo de Cultura Económica, 1980 [original de 1651].

Hohfeld, W., Conceptos jurídicos fundamentales, México D.F., Fontamara, 1992 [original de1913].

Ihering, R., La lucha por el derecho, Granada, Comares, 2011 [original de 1865].

Jellinek, G., Teoría general del Estado, (2. ${ }^{a}$ edición), Buenos Aires, Albatros, 1954 [original de 1911]. 
Kant, E., La metafisica de las costumbres, Madrid, Tecnos, 2005 [original de 1797].

Kelsen, H.,

-- Problemas capitales de la teoría jurídica, México D.F., Porrúa, 1987 [original de 1923].

-- De la esencia y valor de la democracia, Oviedo, KRK Ediciones, 2009 [original de 1929].

.- “¿Quién debe ser el defensor de la Constitución?", en Schmitt, C. y Kelsen, H., La polémica Schmitt/Kelsen sobre la justicia constitucional: El defensor de la Constitución versus ¿Quién debe ser el defensor de la Constitución?, Madrid, Tecnos, 2009 [original de 1931].

.- Teoría pura del Derecho, (2. a edición) México D.F., Porrúa, 1991 [1960].

Laporta, F., "Sobre el concepto de derechos humanos", Doxa, 4, 1987. MacCormick, N., "Los derechos de los niños: una prueba de fuego para las teorías de los derechos", Anuario de Filosofia del Derecho, 5, Madrid, 1988 [original de 1975], págs. 293-305.

Marshall, T.H., Ciudadanía y clase social, Madrid, Alianza, 1998 [original de 1950].

Martínez de Pisón, J., "Los derechos sociales: unos derechos controvertidos", en Zapatero, V. y Garrido, M.I. (eds.), Los derechos sociales como una exigencia de la justicia, Madrid, Cuadernos democracia y derechos humanos, Universidad de Alcalá, 2009, págs. 89-111.

Michelon, C., "Introducción: derechos sociales y la dignidad de la igualdad", Discusiones, 4

Nino, C.,

.- Introducción al análisis del derecho, Buenos Aires, Astrea, 1980.

-- Ética y derechos humanos. Un ensayo de fundamentación, Astrea, Buenos Aires, 1989 [original de 1984].

Peces-Barba, G.,

.- "Los derechos económicos, sociales y culturales: apunte para su formación histórica y su concepto", en Derechos sociales y positivismo jurídico, Madrid, Dykinson, 1999, págs. 7-66.

.- "Los derechos sociales: apuntes políticos y jurídicos", en Zapatero, V. y Garrido, M.I. (eds.), Los derechos sociales como una exigencia de 
la justicia, Madrid, Cuadernos democracia y derechos humanos, Universidad de Alcalá, 2009, págs. 19-36.

Pérez Luño, A., Los derechos fundamentales, Madrid, Tecnos, 1984.

Pisarello, G., Los derechos sociales y sus garantías. Elementos para una reconstrucción, Madrid, Trotta, 2007.

Prieto Sanchís, L., Estudios sobre derechos fundamentales, Madrid, Debate, 1990.

Pufendorf, S., The Books of Elements of Universal Jurisprudence, Indianápolis, Liberty Fund, 2009 (1660).

Rawls, J., Teoría de la justicia, México D.F., Fondo de Cultura Económica, 1995 [original de 1971].

Raz, J., La ética en el ámbito público, Barcelona, Gedisa, 2001 [original de 1994].

Rossetti, A., "Algunos mitos, realidades y problemas en torno a los derechos sociales", en Ribotta, S. y Rossetti, A. (eds), Los derechos sociales en el siglo XXI. Un desafio clave para el derecho y la justicia, Madrid, Dykinson, 2010, págs. 101-126.

Ruiz Miguel, A.,

.- "Derechos liberales y derechos sociales", Doxa, números 15-16, 1994, págs. 651-674.

-- Una filosofia del derecho en modelos históricos. De la antigüedad a los inicios del constitucionalismo, Madrid, Trotta, 2002.

Ruiz-Tagle, P., "Un proyecto constitucional para la generación del bicentenario: Igualdad y derechos sociales y económicos en Chile", Revista de Derecho y Humanidades, número 15, 2009, págs. 17-35.

Searle, J.,

-- La construcción de la realidad social, Barcelona, Paidós, 1997 [original de 1995].

-- Actos de habla. Ensayo de Filosofia del Lenguaje, Madrid, Cátedra, 2007 [original de 1969].

Shapiro, S., Legalidad, Madrid, Marcial Pons, 2014 [original de 2011]. Spinoza, B., Tratado teológico-político, Madrid, Alianza, 2003 [original de 1670]. 
Strawson, P., Análisis y metafisica, Barcelona, Paidós, 1997 [original de 1992].

Thomasius, C., Fundamentos de derecho natural y de gentes, Madrid, Tecnos, 1994 [original de 1705].

Tugendhat, E., Lecciones de ética, Barcelona, Gedisa, 2010 [original de 1993].

Villavicencio, L., Las críticas comunitaristas al liberalismo igualitario. Un balance, Madrid, Dykinson, 2014.

Villey, M., Estudios en torno a la noción de derechos subjetivos, Valparaíso, Ediciones Universitarias, 1976.

Waldron, J., Derecho y desacuerdos, Madrid, Marcial Pons, 2005 [original de 1999]. 